\title{
Perception of Diploma in Accountancy students on ethics education
}

\author{
Nor Sharizad Zainal Abidin ${ }^{1, *}$, and A.H. Fatima ${ }^{2}$ \\ ${ }^{1}$ Kolej Profesional Mara Indera Mahkota \\ ${ }^{2}$ International Islamic University Malaysia
}

\begin{abstract}
The aim of this study is to determine the perception of Diploma in Accountancy (DIA) students on whether ethics should be integrated into the DIA curriculum. This study also investigates the reasons for their opinion. In order to meet these objectives, 100 questionnaires were distributed to final year DIA students of Kolej Professional MARA (KPM). Based on the findings from 96 respondents, two-thirds majority were in support of ethics education in the DIA programme. These students, who agree to ethics integration, were primarily of the opinion that ethics was crucial to the accounting profession, and if ethics were not taught, ethical scandals involving the profession would persist. On the other hand, the one-third minority, who disagree that ethics should be integrated, were mainly of the opinion that there were insufficient materials to teach ethics, accounting lecturers were unwilling or lacked qualifications to teach ethics, and ethical training could not take place in a classroom setting. These concerns of the DIA students should be taken into consideration by the Ministry of Education (MOE) and KPM, should they want to be in line with Halatuju 3.
\end{abstract}

\section{Introduction}

The importance of professional ethics has been spurred by global business scandals. Ethics in the accounting profession is vital, hence the International Federation of Accountants (IFAC) has stressed the integration of ethics into the accounting curricula [1]. The Reassessment Report on Accounting Programmes (Halatuju 3), which was issued by the Ministry of Higher Education (now Ministry of Education, MOE) and the Malaysian Institute of Accountants (MIA), in collaboration with the universities in Malaysia, reemphasises the requirement to integrate ethics into the accounting curriculum [2]. In Malaysia, accredited accounting programmes are required to be in line with Halatuju 3. This reassessment report is only for accounting programmes, whereas some other professional programmes have their own reassessment reports. Since Halatuju 3 affirms the importance of ethics, it is necessary for all accounting programmes in Malaysia to integrate ethics into their curriculum.

Kolej Profesional Mara (KPM) offers Diploma in Accountancy (DIA) programme. The students that graduate from the DIA programme can pursue a degree in Bachelor of Accountancy or sit for professional examinations en route to becoming a professional accountant. Graduates from the DIA programme can also start working in accounting related jobs. Thus, it is equally important to integrate ethics into the DIA programme, in line with the aspirations of IFAC and Halatuju 3.

Currently, the DIA programme has a standalone ethics course, i.e. Business ethics, to impart ethics education to DIA students. This course mainly provides the fundamentals and principles of ethics in general and does not necessarily put ethics into context of practical

\footnotetext{
*Corresponding author: author@email.org
} 
accounting. Previously, lessons on ethics were also integrated into the Accounting Theory and Practice (ATAP) course. The integration of ethics into courses is essential [3], particularly a course on accounting practice, to ensure that the students do not compartmentalise ethics separately from accounting.

Regardless of ATAP being the only course in the DIA curriculum that formally integrates ethics into accounting subject matter, in July 2015 the ATAP course was replaced by Taxation 2. As a result of this change to the curriculum, the only course that formally integrates ethics into the programme is Business ethics, as mentioned above. Consequently, the integration of ethics into the standard DIA curriculum seems to be diminishing. Moreover, by only having a standalone course, without formal ethics integration into accounting subject matter, there is a concern that students may consider ethics to be idealistic and fail to establish the connection between ethics and accounting. Failing to integrate ethics into accounting would jeopardise ethics education in the DIA programme, which would be contrary to the aims of Halatuju 3.

As the DIA students are affected by this change in curriculum, it is necessary to get their viewpoint on ethics education. Therefore, the aim of this study is to determine whether in the opinion of DIA students, there is a need for ethics education in the DIA programme and the reasons for their opinion. Although studies have been conducted on ethics education [4], none have considered the viewpoint of students at the diploma level. This study would thus be beneficial to KPM to attain the opinions of their key stakeholders, i.e. the students. Moreover, the findings may also be useful to KPM and MOE for them to consider in their evaluation of the new curriculum.

The next section reviews the literature. Then, the discussion proceeds with the theory generally referred to in ethics studies as well as the research method. The findings are analysed prior to concluding the study.

\section{Literature Review}

There are two main areas in ethics education literature: (1) ethics education on moral reasoning, ethical awareness or ethical sensitivity [5, 6, 7], and (2) perception on ethics education. Generally, the first group of studies find that ethical reasoning, awareness and sensitivity are enhanced subsequent to certain forms of ethics education. In the context of Malaysia, the ethical attitude of 210 final year accounting students from a public university was tested [8]. The study investigated whether the students were willing to take a bribe or defraud shareholders (under two circumstances: will not get caught and $10 \%$ chance of getting caught) and their attitude towards whistle blowing. The study concluded that it is crucial for universities to inculcate ethics, in line with Halatuju 3.

In relation to studies on the perception of ethics education, these studies tend to focus on the educators' perspective $[3,4,9,10]$. These studies are carried out in the United States of America (US) [3], Japan [10] and Malaysia [4, 9]. The educators generally perceive that ethics should be integrated into the accounting curricula $[3,4,9,10]$. Ethics is embedded in relevant courses [9] or both, taught as a standalone course as well as integrated into various courses $[4,10]$. The accounting educators deem that they are most appropriate to teach ethics to accounting students [3].

The review of the literature above has highlighted that the perception of DIA students on ethics education is lacking and this gap needs to be filled. 


\section{Theory and Research Method}

Kohlberg theorised the "Cognitive Moral Development" of an individual, which was later developed into a four-component moral process model by Rest [11]. Kohlberg's and Rest's moral development processes were further extended into Thorne's Integrated Model (TIM). The model prescribes gradual development of ethical behaviour through ethics education. Thus, even though TIM is not a theory, it is referred to by several prior studies [12, 13, 14] in relation to ethics, as well as in support of ethics education.

Based on the above, although TIM provides support for ethics education in general, it does not explain the possible perception of students on ethics education. Therefore, the current study is exploratory in nature as it aims to determine the perception of DIA students on ethics education. Considering that it would be difficult to predict the perception of these students, hence a hypothesis cannot be framed in this study.

This study collected primary data from DIA students using survey approach. The questionnaire was adopted from prior Malaysian literature [4] that adapted the instrument from an earlier US study [3]. The questionnaire comprise four sections: Section A gathers the demographic details of the respondents. Section B consists of a filtering question. The respondents were required to answer "Yes" or "No" to this question. If the respondents perceived that ethics should indeed be integrated into the DIA programme, they were required to answer Section C, if not, they were requested to proceed to Section D.

Section C solicited DIA students' reasons for ethics integration. On the other hand, Section D enquired on students' reasons for disagreeing to ethics being integrated into the programme. Both Sections C and D used a five-point Likert scale ranging from (1) for 'strongly disagree' to (5) for 'strongly agree' to elicit the responses of students.

Subsequent to performing a pilot test, 100 copies of the questionnaire were distributed to final year DIA students from four KPMs: KPM Beranang, Selangor; KPM Air Molek, Melaka; KPM Bandar Penawar, Johor Bharu and KPM Indera Mahkota, Kuantan. The final year students were selected as the sample of study as they had undergone the DIA programme and were better able to provide an opinion on whether ethics education would be warranted in the programme. Since the questionnaires were distributed through the Heads of department, it enabled a response rate of $96 \%$.

In addition to the descriptive statistics to analyse the demographics of the respondents, Cronbach's alpha was used to test the reliability of the questionnaire instrument. Then, means were used to measure the responses on reasons to have or not to have ethics education in the DIA programme.

\section{Results and Discussion of Findings}

Based on the Cronbach's alpha, the questions on reasons for having ethics education and not having ethics education were 0.809 and 0.804 , respectively. Cronbach's alpha of above 0.8 is considered to be high in reliability [15]. Out of the 96 respondents, $59.4 \%$ were female students. Then, in answering Section B, 66.7\% of the respondents were of the opinion that ethics should indeed be integrated into the DIA programme. Surprisingly, a third of the respondents were of the opinion that ethics should not be integrated into the DIA programme. The percentage of dissenting respondents is high and contrary to prior literature [4]. Their opinion also contradicts the recommendation by IFAC and Halatuju 3.

Table 1 below lists the reasons, based on DIA students' perception, for integrating ethics into the DIA programme. The list is no longer in the order as it is in the questionnaire, as it has been ranked in accordance to the highest to lowest mean. 
Table 1. Reasons in support of integrating ethics in the DIA programme

\begin{tabular}{|l|c|}
\hline \multicolumn{1}{|c|}{ Statements } & Means \\
\hline $\begin{array}{l}\text { Failure to teach ethics in the accounting curriculum contributed to } \\
\text { recent business scandals }\end{array}$ & 4.25 \\
\hline It is important for accountants to be ethical & 3.74 \\
\hline $\begin{array}{l}\text { Ethical development is crucial to the accounting profession since it } \\
\text { is required by MIA }\end{array}$ & 3.74 \\
\hline Students' ethical awareness has declined over the years & 3.66 \\
\hline $\begin{array}{l}\text { MIA may lose its authority to regulate the profession if ethical lapse } \\
\text { continues }\end{array}$ & 3.59 \\
\hline $\begin{array}{l}\text { There seems to be a decline of ethical awareness amongst } \\
\text { accounting students in Malaysia }\end{array}$ & 3.57 \\
\hline $\begin{array}{l}\text { To prepare students to make ethically sensitive decisions instead of } \\
\text { just focusing on figures }\end{array}$ & 3.34 \\
\hline Students do not seem to be getting adequate ethical training & 3.33 \\
\hline $\begin{array}{l}\text { Public trust needs to be re-established due to recent accounting } \\
\text { scandals }\end{array}$ & 3.13 \\
\hline
\end{tabular}

The means above indicate that the DIA students are concerned that the failure to teach ethics would contribute to business scandals. These students perceive, and rightly so, that being ethical and ethical development is crucial to the accounting profession. The students generally consent that students' ethical awareness has declined over the years, but their agreement is marginally less on accounting students' ethical awareness has also declined. Finally, the DIA students are concerned that MIA may lose their authority if ethical scandals involving the accounting profession persist.

The DIA students tend to be more 'neutral' about the last three statements as their means are close to ' 3 '. These findings could be interpreted as the students being relatively indifferent about enabling students to make ethically sensitive decisions. In general, they also seem undecided on whether there is adequate ethics training and on regaining public trust subsequent to ethical scandals.

In contrast, Table 2 below lists the reasons of the DIA students who are of the opinion that ethics education should not be included in the DIA programme.

Table 2. Reasons in support of not integrating ethics into the DIA programme

\begin{tabular}{|l|c|}
\hline \multicolumn{1}{|c|}{ Statements } & Means \\
\hline There is inadequate materials for teaching ethics & 4.50 \\
\hline Normally, accounting lecturers are not willing to teach ethics & 4.40 \\
\hline Ethics cannot be taught & 4.30 \\
\hline Accounting lecturers may not be qualified to teach ethics & 4.00 \\
\hline $\begin{array}{l}\text { Students cannot adequately be trained in classrooms to deal with "real } \\
\text { world" ethical dilemmas }\end{array}$ & 3.80 \\
\hline $\begin{array}{l}\text { Responsibility of encouraging ethical values should be left to parents } \\
\text { and family members }\end{array}$ & 3.80 \\
\hline $\begin{array}{l}\text { Teaching ethics in the Diploma Accounting curriculum is only a } \\
\text { strategy to please the public as a result of recent accounting scandals }\end{array}$ & 3.79 \\
\hline Diploma Accounting curriculum is not an appropriate place to teach & 3.70 \\
\hline
\end{tabular}




\begin{tabular}{|l|l|}
\hline ethics & \\
\hline $\begin{array}{l}\text { There is little or no time to teach ethics in the current Diploma } \\
\text { Accounting curriculum }\end{array}$ & 3.61 \\
\hline
\end{tabular}

The students that perceive that ethics should not be integrated into the DIA accounting programme generally were of the opinion that there were inadequate materials for teaching ethics. They also perceived that accounting lecturers are not willing to teach ethics or were not qualified to do so. This is the perspective of the DIA students, thus future research should also consider seeking the perspective of the DIA lecturers to determine if they have the same opinion.

These students also perceived that ethics cannot be taught, or at least facing 'real world' ethical dilemmas cannot be taught in classrooms. These DIA students were also of the opinion that some responsibility of imparting ethical values to the students should be borne by the parents and family members.

These DIA students deem that teaching ethics in the DIA programme is merely a ploy to appease the public's reaction to the business scandals. They consider that the DIA curriculum is not the appropriate place to integrate ethics, possibly because there is little time to add lessons on ethics in the current DIA curriculum.

It is difficult to compare the findings of the perception of DIA students on ethics integration as prior literature tend to be on the perception of educators at the undergraduate level of study. Also, the findings from prior literature tend to be in support of ethics education [4].

\section{Conclusion}

In analysing the results above, the DIA students, who support the integration of ethics education, realise the importance of ethics to the accountancy profession. Their perception is in line with those of IFAC and Halatuju 3. However, the findings on the dissenting students' reasons are more imperative. This is because, although a minority, a third of the respondents is still a significant proportion of the sample, and considerably higher to prior studies [4]. Therefore, should the MOE and KPM want the DIA curriculum to be in line with IFAC and Halatuju 3 guidelines, then the concerns of these students should be addressed.

Firstly, the MOE could consider giving research grants to academics and researchers to develop ethical cases in the context of Malaysia to alleviate the concern on lack of teaching materials in relation to ethics. Moreover, KPM should collaborate with MOE to train all teachers and lecturers at school and tertiary institutions on approaches to teaching ethics, imparting ethical values and becoming role models for students. Furthermore, the perception that accounting lecturers are unwilling to teach ethics should be studied further, as it could be a misconception of students. This is because prior literature suggests that the accounting educators perceive that they are the most appropriate to teach ethics [3].

Then, the issue that ethics cannot be taught has to be alleviated. The concept and models developed by Kohlberg, Rest and Thorne propose that ethical development is in stages, hence should take place as early in an individual's life as possible. Therefore, it may not be appropriate to leave ethics education to be integrated only at the tertiary level in the Bachelor of Accountancy (BAcc) programme. Thus, the KPM may have to consider integrating ethics into accounting courses as the ATAP course has been removed from the DIA curriculum. A standalone course on Business Ethics may be insufficient.

Certain limitations of the study must be noted. Firstly, the study was only conducted on a sample of DIA students. Hence, future studies can be extended to also consider other 
diploma students as well as the educators' perspective on ethics education. Future studies could also consider having focus group discussions and interviews with students as well as educators to confirm the findings of this study.

\section{References}

1. C. O'Leary, S. Mohamad. Mal. Acc. Rev. 7, 1 (2008)

2. Halatuju 3, Ministry of Higher Education (2015)

3. C. Blanthorne, S.E. Kovar, D.G. Fisher. Iss. Acc. Ed. 22, 355 (2007)

4. Y. Y. Win, S. Ismail, A.H. Fatima. Mal. Acc. Rev. 13, 1 (2014)

5. M. J. Abdolmohammadi. R. Prof. Res. \& Ethics Acc. 10, 37 (2005)

6. M. P. Coyne, D.W. Massey, J.C. Thibodeau. Adv. Acc. Ed. 7, 171 (2005)

7. M. J. Billiot, D. Daniel, S. Glandon, T. Glandon. Am. J. Bus. Ed. 5, 277 (2012)

8. N. Abu Bakar, S. Ismail, S. Mamat. J. Fin. Rep. \& Acc. 6, 21 (2008)

9. J. Singh, M. Poduval. Proceedings $2^{\text {nd }}$ Conf. Teaching \& Learning (2009)

10. S. Sugahara, G. Boland. R. Prof. Res. \& Ethics Acc. 15, 193 (2011)

11. J.R. Rest. A psychologist look at the teaching of ethics (Hastings Center Report 1982)

12. M. B. Armstrong, J.E. Ketz, D. Owsen. (2003). J. Acc. Ed. 21, 1 (2003)

13. C. Y. Loh, J.B. Wong. Aus. Acc. Bus. \& Fin. J. 3, 3 (2009)

14. N. L. Ahmad. Mal. J. Society \& Space, 11 (2015)

15. U. Sekaran, R. Bougie. Research methods for business (John Wiley \& Sons, UK 2013) 